\title{
Real-Time, Variable-Depth Tillage for Managing Soil Compaction in Cotton Production
}

\author{
Jonathan W. Fox', Ahmad Khalilian1*, Young J. Han1, Phillip B. Williams1, Ali Mirzakhani Nafchi', \\ Joe Mari Maja², Michael W. Marshall ${ }^{2}$, Edward M. Barnes ${ }^{3}$ \\ ${ }^{1}$ Department of Agricultural Sciences, Clemson University, Clemson, SC, USA \\ ${ }^{2}$ Edisto Research and Education Center, Clemson University, Blackville, SC, USA \\ ${ }^{3}$ Cotton Incorporated, Cary, NC, USA \\ Email: jwfox@g.clemson.edu, ^akhlln@clemson.edu, yhan@clemson.edu,pbw@clemson.edu, anafchi@clemson.edu, \\ jmaja@clemson.edu,marsha3@clemson.edu,EBarnes@cottoninc.com
}

How to cite this paper: Fox, J.W., Khalilian, A., Han, Y.J., Williams, P.B., Nafchi, A.M., Maja, J.M., Marshall, M.W. and Barnes, E.M. (2018) Real-Time, Variable-Depth Tillage for Managing Soil Compaction in Cotton Production. Open Journal of Soil Science, 8, 147-161.

https://doi.org/10.4236/ojss.2018.86012

Received: May 16, 2018

Accepted: June 22, 2018

Published: June 25, 2018

Copyright $\odot 2018$ by authors and Scientific Research Publishing Inc. This work is licensed under the Creative Commons Attribution International License (CC BY 4.0).

http://creativecommons.org/licenses/by/4.0/

\begin{abstract}
Cotton root growth is often hindered in the Southeastern U.S. due to the presence of root-restricting soil layers. Tillage must be used to temporarily remove this compacted soil layer to allow root growth to depths needed to sustain plants during periods of drought. However, the use of a uniform depth of tillage may be an inefficient use of energy due to the varying depth of this root-restricting layer. Therefore, the objective of this project was to develop and test equipment for controlling tillage depth "on-the-go" to match the soil physical parameters, and to determine the effects of site-specific tillage on soil physical properties, energy requirements, and plant responses in cotton production. Site-specific tillage operations reduced fuel consumption by $45 \%$ compared to conventional constant-depth tillage. Only $20 \%$ of the test field required tillage at recommended depth of $38-\mathrm{cm}$ deep for Coastal Plain soils. Cotton taproot length in the variable-depth tillage plots was $96 \%$ longer than those in the no-till plots ( 39 vs. $19.8 \mathrm{~cm}$ ). Statistically, there was no difference in cotton lint yield between conventional and the variable-depth tillage. Deep tillage (conventional or variable-rate) increased cotton lint yields by $20 \%$ compared to no-till.
\end{abstract}

\section{Keywords}

Variable-Rate Tillage, Cotton, Soil Compaction, Precision Agriculture, Energy

\section{Introduction}

Cotton root growth is often hindered in the Southeastern U.S. due to the presence of root-restricting soil layers. In this region, the hardpan layer exhibits a 
great amount of variability in depth and thickness, and usually is present in the profile at the 25 to $40 \mathrm{~cm}$ depth and is typically 5 to $20 \mathrm{~cm}$ thick [1] [2] [3]. The hardpan layer has a significantly higher bulk density that limits the ability of the plant roots to penetrate into the sub-soil for uptake of water and nutrients, therefore, reducing yields, limiting productivity, and making plants more susceptible to drought stress [2]. Soil compaction is managed in the Southeastern U.S. using annual uniform-depth tillage before planting, to allow root growth to depths needed to sustain plants during periods of drought, which have been shown to improve yields [2] [3] [4] [5] [6]. The recommended tillage depth for Coastal Plain regions is usually about 35 to $40 \mathrm{~cm}$ deep [7] [8] [9] [10]. Due to significant variability in depth and thickness of hardpan layers in Coastal Plain soils [1] [11], applying uniform-depth tillage over the entire field may be either too shallow to fracture the hardpan or deeper than required resulting in excess fuel consumption and an inefficient use of energy.

Ideally, the depth and thickness of the hardpan layer needs to be determined for the optimum tillage depth to remove the hardpan layer [1]. Also, there is little benefit from tilling deeper than required to fracture the compacted layer and in some cases; penetration into the clay layer (sub-soil) may be detrimental [12]. Previous research has shown that tilling $7.5 \mathrm{~cm}$ deeper than the clay layer increased draft requirements by $75 \%$ and fuel consumption by $50 \%$, without increasing cotton yields. Also, using spatial cone index measurements to map the variability of the hardpan showed that approximately $75 \%$ of the field required a tillage depth less than $38 \mathrm{~cm}$, the recommended tillage depth for coastal plains soils [11] [13]. Therefore, this variability leads us to believe that, by adjusting tillage depth on-the-go to match the depth and thickness of the hardpan layer could lead to significant savings in tillage energy.

Several researchers have attempted continuous measurement of soil strength at multiple depths [14]-[22]. In addition, map-based equipment for changing tillage depth on-the-go was developed by Clemson researchers [23]. However, currently, there is no equipment available to automatically control the tillage depth to match the soil physical properties.

\section{Objectives}

The objectives of this study were: A) to develop and test equipment for controlling tillage depth "on-the-go" to match soil physical parameters; B) to determine feasibility of using site-specific tillage to alleviate root-restrictions to improve yield; and C) to quantitatively determine the effects of site-specific tillage on soil physical properties, energy requirements, and plant responses in cotton production.

\section{Methodology}

\subsection{Design Criteria}

A variable-depth tillage system called "the Clemson Intelligent Plow" was de- 
signed and constructed using the following criteria. The system will:

- Measure and record mechanical impedance of soil at multiple depths over the entire top $45-\mathrm{cm}$ of soil profile while moving through the soil.

- Calculate the depth and thickness of the hardpan layer, based on modified algorithm provided by Gorucu [1].

- Control tillage depth on-the-go based on inputs from the instrumented shank, prescription maps, or manually from the tractors' cab.

- Communicate with a GPS receiver.

- Measure and record fuel consumption and tillage depth during the operation.

- Incorporate user-friendly software and control system.

\subsection{Instrumented Shank}

The instrumented shank developed at Clemson University [22] [23] was modified for determining the mechanical impedance of soil at multiple depths over the entire top $45-\mathrm{cm}$ of soil profile while moving through the soil. The length of the instrumented shank was changed for use with the variable depth tillage system. A $2.5-\mathrm{cm}$ thick by $15.3-\mathrm{cm}$ wide flat bar was used for this purpose. The new shank length was $163-\mathrm{cm}$ long. The instrumented subsoiler shank consisted of five $7.5-\mathrm{cm}$ long sections attached to the subsoiler shank using load cells. The width of each section was $2.5 \mathrm{~cm}$, and the face of each section was flat and perpendicular to the direction of travel. Two compression load cells (Model MSSPCOMP, 8896-N National Scale Technology-Huntsville, AL, USA) were used in each $7.5-\mathrm{cm}$ section to measure the horizontal force acting on the subsoiler shank (Figure 1).

The sum of two load cells was used to calculate the total force acting on each section of the instrumented shank. Dividing the horizontal force by the area of

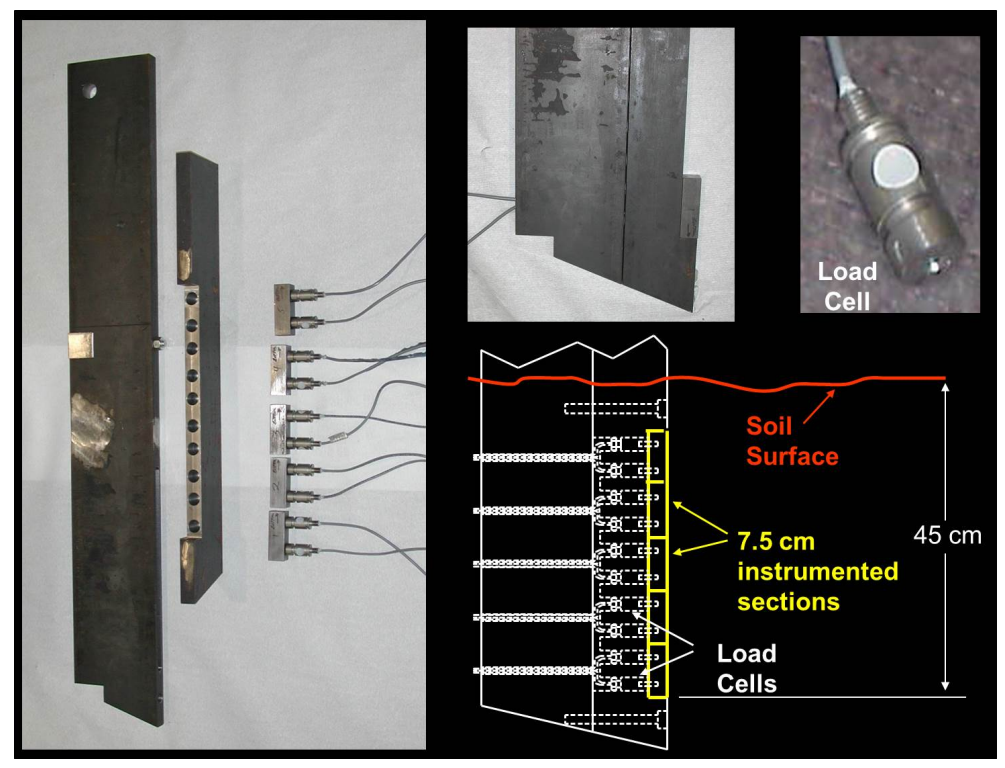

Figure 1. Design and the individual components of the instrumented shank (adapted from Khalilian et al., 2014 [22]). 
the load cell plate $19-\mathrm{cm}^{2}$ resulted in the amount of pressure acting on the plate, which is called the "shank index or SI" [13]. The shank index then was converted to cone index values using the following equation [22].

$$
C I=1.5089 * S I+0.7801
$$

where CI stands for cone index and SI stands for shank index. This conversion makes it possible to use standard methods for the maximum allowable level of compaction (2.07 MPa) [24] for optimum crop performance, to determine the depth and thickness of the hardpan layer.

\subsection{Depth Control System}

GPS-based equipment for controlling the tillage depth to match soil physical parameters was developed. The gage wheels on a four-row subsoiler were attached to an electro-hydraulic actuator (Parker Hannifin Co. model 03.25BB-HXLTS24A, www.parker.com). The actuator moves the gage wheels upward or downward to control the tillage depth on-the-go. The hydraulic cylinder is equipped with a dual element type linear potentiometer, which provides an analog feedback signal of the cylinder's position. The spool of a proportional directional control valve (Parker series D1FX-CK, www.parker.com) shifts in either direction in response to variable command signals, thus providing the desired length of extension of the hydraulic cylinder. Once the spool reaches the desired position, the internal potentiometer sends a feedback signal to the drive amplifier, which maintains that position.

The proportional directional control valve was controlled by a negative five volts to positive five volts direct current signal. When positive five volts was applied to the control system, the cylinder would retract to fully closed position, corresponding to $45-\mathrm{cm}$ tillage depth. The opposite effect for negative five volts would fully extend the electro-hydraulic actuator correspondent to zero tillage depth. This system can then extend the hydraulic cylinder to any length in-between zero and $45-\mathrm{cm}$.

\subsection{The Clemson Intelligent Plow}

The Clemson Intelligent Plow was developed to mount directly on the tractor and continuously measure the depth to the hardpan and adjust the tillage depth accordingly. The new system was designed to measure soil compaction data, calculate the depth and thickness of the hardpan layer, and adjust tillage depth on-the-go for real-time, variable-depth, tillage operations for crop production. This was achieved by combining two systems the "Instrumented Shank" and the "Depth Control System" described above. The new system was designed using SOLIDWORKS software (Dassault Systèmes SolidWorks Corporation, Waltham, MA) to allow for fabrication of all necessary components. Figure 2 illustrates the 3D sketch of the new design. With this system, tillage depth can be changed from zero to $45 \mathrm{~cm}$. Inputs for decision-making could be from the instrumented shank (real time) or controlled manually with a one-turn 


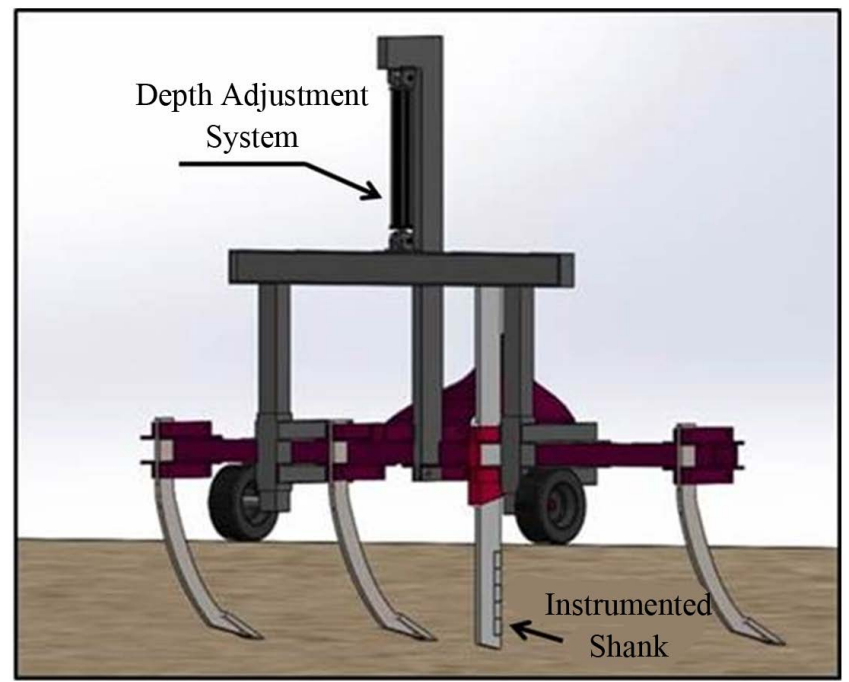

Figure 2. Solid Works rendering of the Clemson Intelligent Plow.

potentiometer located inside the tractor cab.

The instrumented shank was attached to the system using two L-brackets bolted to the top bar of the gauge wheels. Also, the shank was supported using four L-brackets on the main beam of the four-row subsoiler. Teflon spacers were added between the brackets to ensure that the instrumented shank would not bind and have the ability to move smoothly. A solid steel roller wheel (5-cm diameter) with a $1.25-\mathrm{cm}$ sheer pin was used to protect the instrumented shank, to keep it at a 90 degree vertical orientation, and to ensure that it would freely move with respect to the remaining three subsoiler shanks. Once the final attachments were added and tested the system was painted to reduce the likelihood of corrosion. This is shown in Figure 3.

\subsection{Instrumented Tractor}

An instrumented John Deere 7710 tractor (116 kW) (John Deere Co., Moline, IL, USA) was used to make in field measurements of tractor fuel consumption, and ground speed of the different tillage treatments. The instrumented tractor was equipped with a fuel flow meter (Fuel View DFM-50C-K, www.technoton.com), which produced 200 pulses per liter of fuel that passed through it. The fuel flow meter was then tested to ensure its accuracy, and it was found that the default factory calibration provided was accurate within an error of less than $1 \%$.

\subsection{Data Logger}

The Clemson instrumented shank originally used the LogBook/360 data logger (IOTech, Inc., Cleveland, OH, USA) to collect the compaction data. This system was updated with three Phidgets Wheatstone Bridges (www.phidgets.com) to read the shank index data. Each bridge could read up to four load cells. The bridges output five volt signal to the load cells and measures the return voltage. 


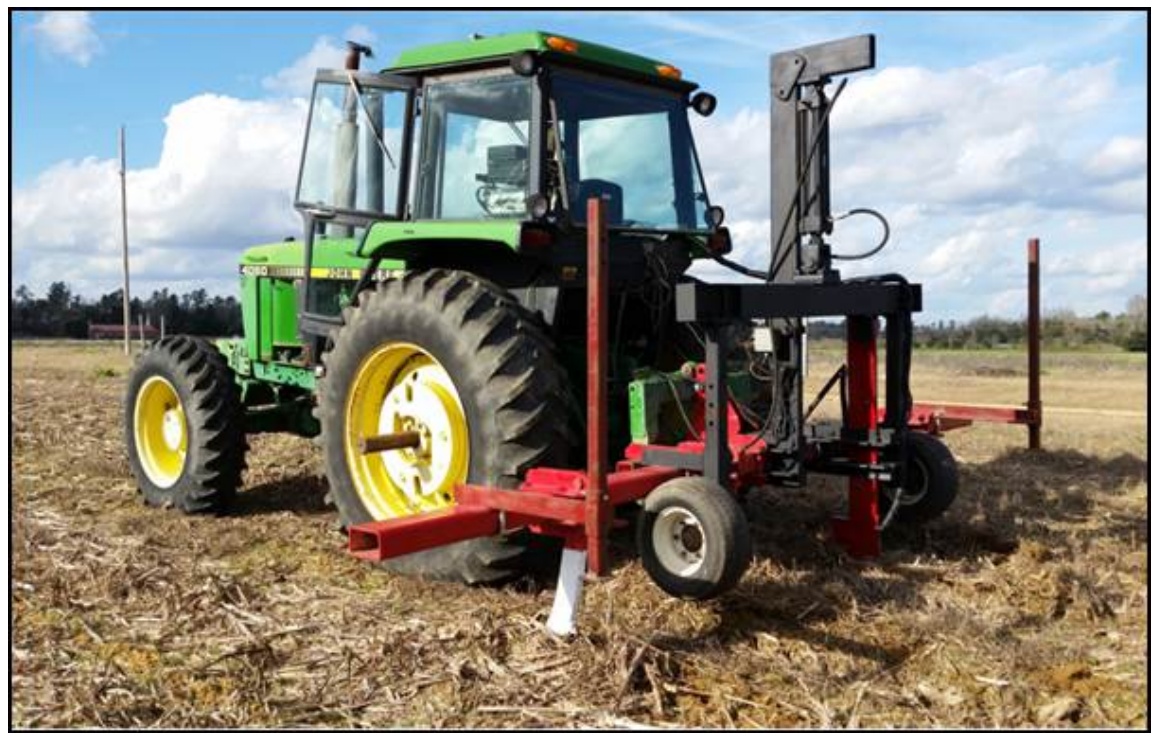

Figure 3. The Clemson Intelligent Plow.

The data are then transferred to an on-board computer via USB cable, where it is used to calculate the pressure on each section of the instrumented shank. The program then converts the measured data into a cone index which can be used in calculating the optimal tillage depth. The optimal tillage depth was calculated on-the-go using an algorithm developed at Clemson University [1].

The Phidgets analog output circuit board sends a plus or minus five-volt DC signal to the hydraulic cylinder control system for adjusting the tillage depth. This made it possible to easily control the tillage depth using custom software described in the next section. A Phidgets frequency counter circuit board was used to read the output of the fuel flow meter and to measure real-time fuel consumption. This also allowed us to measure the average fuel consumption for a given tillage depth for a specific tillage treatment. All of the Phidgets boards were wired into one quick disconnect box (Figure 4), which allowed for easy removal of the entire system from the tractor cab.

\subsection{Custom Software}

Custom software was developed using Visual Basic to support the Clemson Intelligent-Plow. The software enables the user to visualize and log the data from all the instrumentation in real time and control the tillage depth on-the-go. The main software page of this program is shown in Figure 5. This program included the necessary requirements to read output from four Wheatstone bridges, a Phidgets analog output, a Phidgets frequency counter and to receive GPS position from any serial GPS receiver. In addition to allowing the user to control the Clemson Intelligent plow it also monitors fuel-consumption.

In the main page of the custom software, the raw data, as well as the calculated values, are displayed. The optimum tillage depth is calculated as shown in the flow chart below (Figure 6). The program brings all the data in from the 


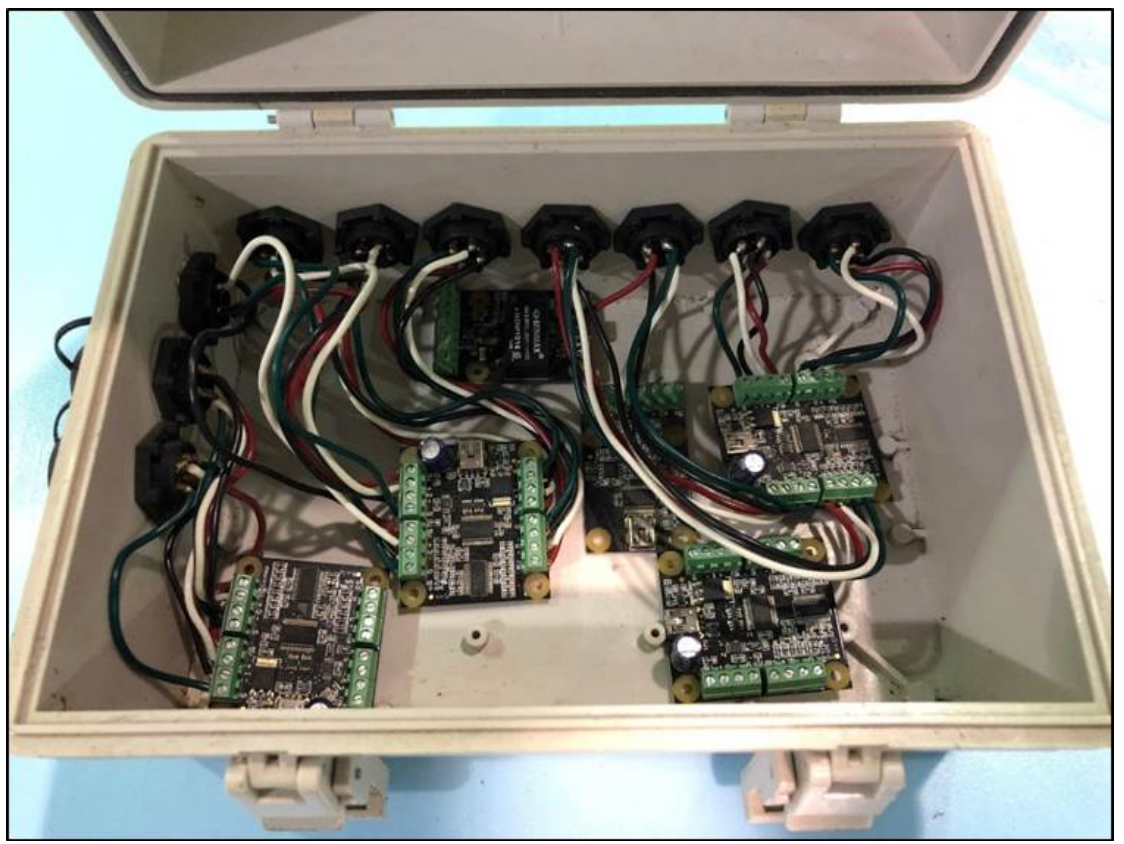

Figure 4. The Phidgets data logger and controller.

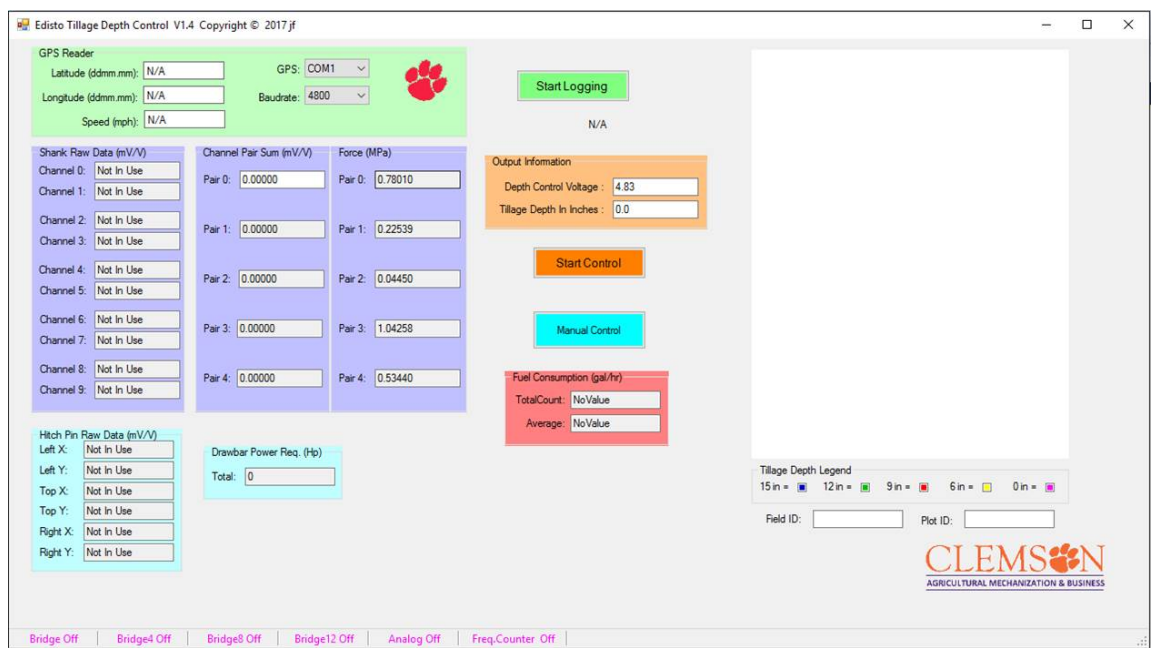

Figure 5. Main page of the Edisto Variable Depth Tillage Program.

instrumented shank, sums each load cell pair, and then converts this raw bridge data to load. Next, the load is converted to MPa and run through the shank index to cone index conversion equation [22], to determine the optimum tillage depth. Lastly, the system sends the control voltage to the hydraulic depth adjustment system. The program is also equipped with GPS tracking to display the user's current position in the field. In addition to the GPS tracking, the software also includes a color-coded icon, which allows the operator to visualize tillage depth at a given location in the field during the tillage operation.

\subsection{Field Tests}

To create a preseason map of the hardpan in the field, a microcomputer-based, 


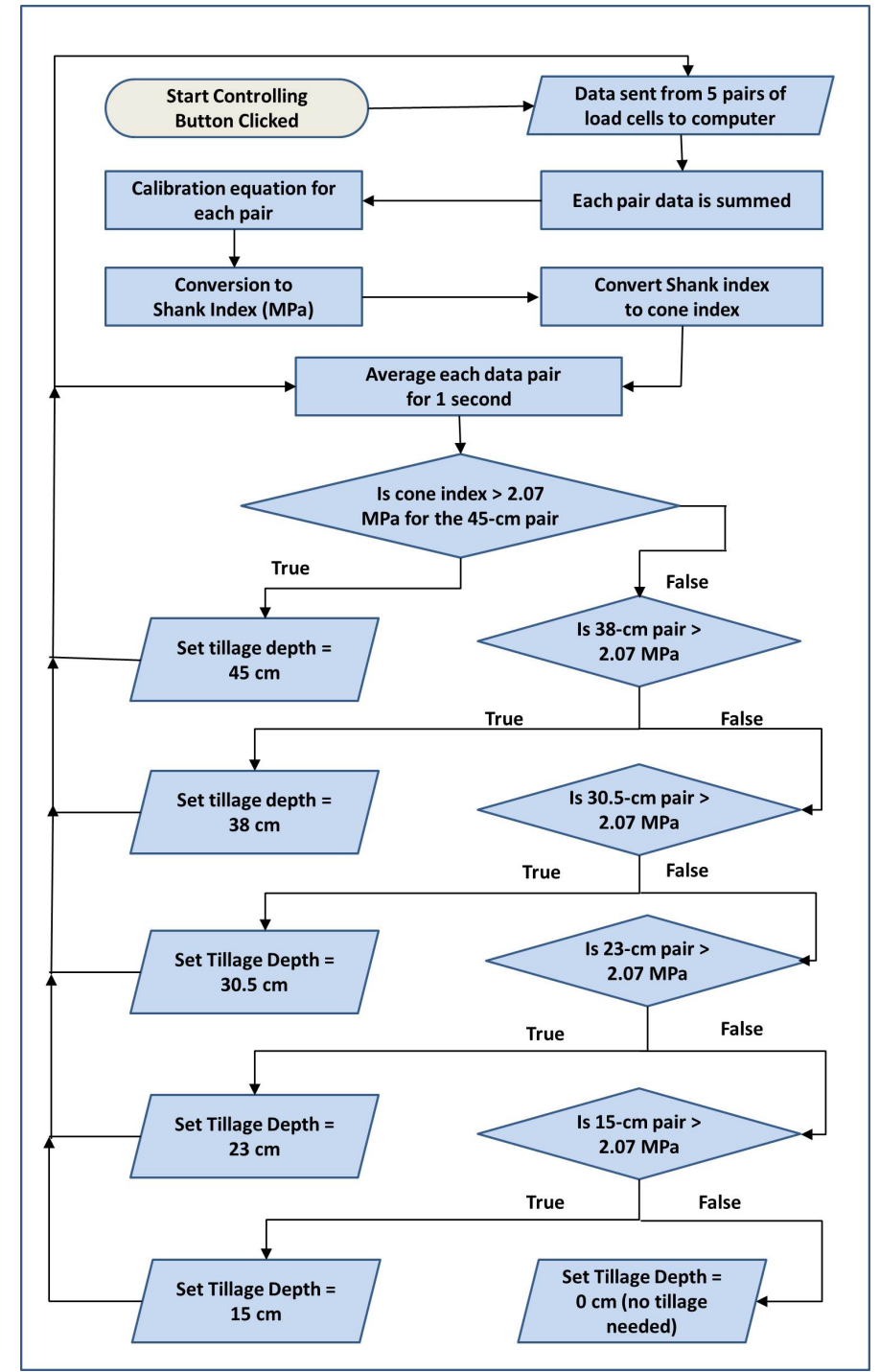

Figure 6. Tillage depth control system logic flow chart.

tractor-mounted recording penetrometer, equipped with GPS system was used to quantify geo-referenced soil penetration resistance in the test field [2]. Soil compaction values were calculated from the measured force required pushing a $3.23 \mathrm{~cm}^{2}$ base area, 30-degree cone into the soil (ASABE Standards, R2013).

Replicated field tests were conducted to determine the performance of the Clemson Intelligent Plow. A one-hectare test field located near Blackville, South Carolina (Latitude $33.359473^{\circ} \mathrm{N}$, Longitude $81.332239^{\circ} \mathrm{W}$ ), was divided into 40 rectangular plots (4-row by $28-\mathrm{m}$ ) and soil compaction data were collected from each plot, before tillage operations and at cotton harvest. Three sets of penetrometer measurements were obtained from each plot. The optimum tillage depth in each plot was determined utilizing the penetrometer data, and an algorithm developed at Clemson University [1].

The following four tillage treatments were applied at random to plots of each zone on May $16^{\text {th }}, 2017$ (Figure 7). A randomized complete block design with 10 


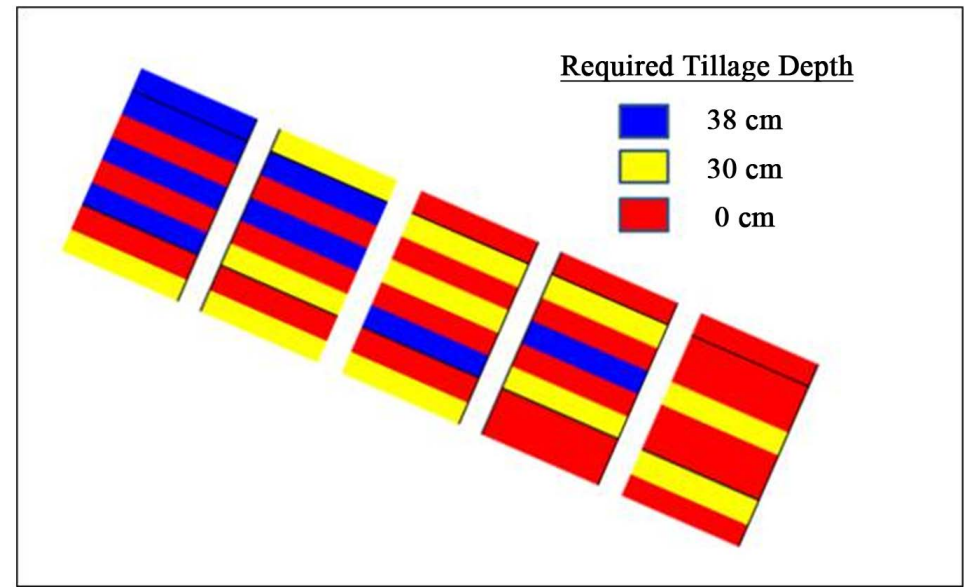

Figure 7. Required tillage depths for the one-hectare test field, 2017.

replications was the statistical model selected for evaluating treatments.

1) Variable depth tillage based on real-time measurements of depth and thickness of the hardpan layer, using the intelligent plow (VDT);

2) Conventional tillage, constant depth, $38-\mathrm{cm}(\mathrm{CON})$;

3) Tillage depth based on average penetrometer data (AP); and

4) No deep tillage operations (NT).

Cotton (Delta Pine 1646-B2XF, Monsanto, St. Louis, MO, USA) was planted on May $18^{\text {th }}, 2017$ using a John Deer 1700 planter (John Deere Co., Moline, IL, USA), and carried to yield using recommended standard production practices for fertilizer and pest control. A second round of penetrometer data was collected post-harvest to determine the effects of the different tillage treatments on soil compaction.

To compare the root growth restrictions between the different treatments, 200 plants were carefully excavated, without breaking the tap root. Five plants per plot were bagged and labeled to keep them all in order. Next, the tap roots were cut off and tap root length, and plant height were measured. All roots were oven dried and weighed to determine root dry weight. Data were analyzed in the SAS software package (SAS v. 9.4, SAS Institute Inc., Cary, NC).

\section{Results}

Figure 7 shows the required tillage depth of the one-hectare test field based on the penetrometer data collected before any tillage operations using the Clemson optimal tillage depth algorithm. Based on average penetrometer data (AP), deep tillage was not needed in $52 \%$ of the test field. Only $20 \%$ of the field required tillage at recommended depth for Coastal Plain regions (38-cm deep).

These results are in agreement with previous tillage research conducted on Coastal Plain soils [11] [25] [26]. They reported that, based on spatial cone index measurements the variability in root-restricting layers showed that about $80 \%$ of the fields required shallower tillage depth than $38-\mathrm{cm}$, the recommended tillage depth for coastal plains soils. With conventional tillage practices, growers are 
unable to completely remove the hard pan layer, without tilling significantly deeper than required; therefore, using significantly more fuel compared to site-specific tillage operations.

As shown in Figure 8, the fuel requirement for "No-Tillage" $(0 \mathrm{~cm})$ was 8.7 1/hr. This amount of fuel was needed for just driving the JD-7710 (116 kW) tractor from one part of the field to another, without performing any tillage operations. Therefore, in this field conventional deep tillage operations $(38-\mathrm{cm}$ deep) would have required 52\% more fuel than site-specific tillage (based on penetrometer data). This provided confirmation that the fuel cost associated with deep tillage could be drastically reduced in Coastal Plain soils.

Statistically, there were no differences in taproot length between variable-depth tillage (VDT), conventional tillage (CON), and tillage depth calculated based on average penetrometer data (AP). However, cotton taproots in the (VDT) plots were 96\% longer than those in the no-till (NT) plots (Figure 9). Also, cotton plant heights in the no-till plots were $10.2 \mathrm{~cm}$ less than those in the variable depth tillage plots. These results were similar as reported by Khalilian et al. (2004) [6]. There was no significant difference between the average-totalroot-weights (ATTW) based on the different tillage treatments. The ATTW values were $12.8,12.7,10.2$, and $10.0 \mathrm{~g}$, for VDT, CON, AP, and NT, respectively.

The results showed that, tillage operations based on either real-time sensor (VDT) or penetrometer data, reduced fuel consumption by $45 \%$ compared to conventional constant-depth tillage (Figure 10). This translates to significant savings in fuel costs. Similar results were reported by Gorucu et al. (2001) [13] and Gorucu et al. (2011) [25]. This significant increase in fuel efficiency further proves the ability of this tillage system to do the same task as conventional systems while decreasing the cost associated with the conventional methods. This allows for farmers to increase profits without sacrificing yield potential. It also

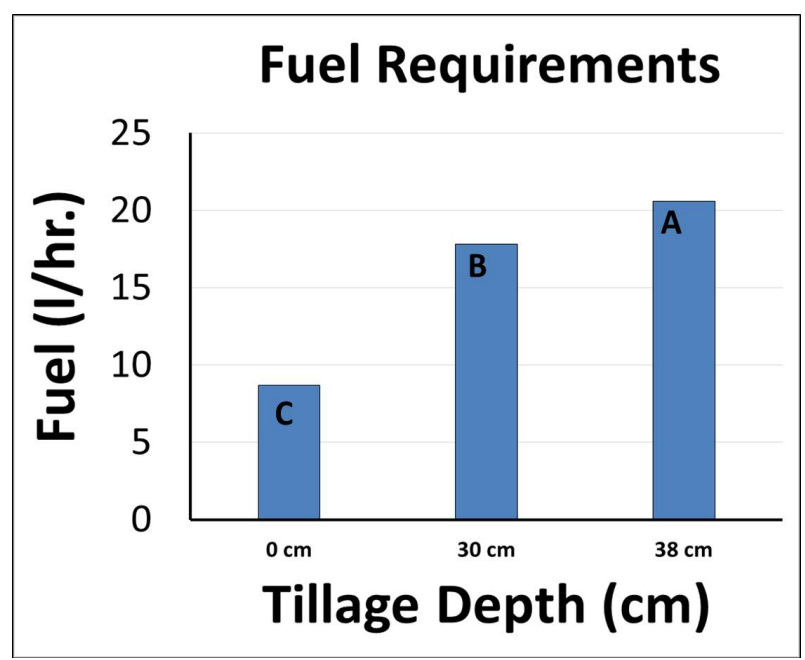

Figure 8. Effects of tillage depth on fuel consumption. Fuel consumption values with the same letter are not significantly different at the $95 \%$ confidence level. 


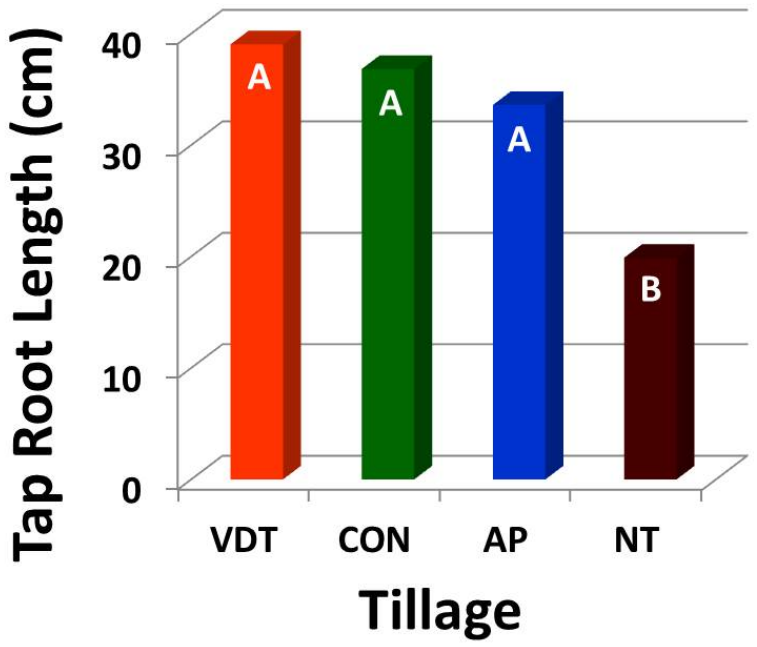

Figure 9. The effect of tillage systems on cotton taproot length. Tap root length values with the same letter are not significantly different at the $95 \%$ confidence level.

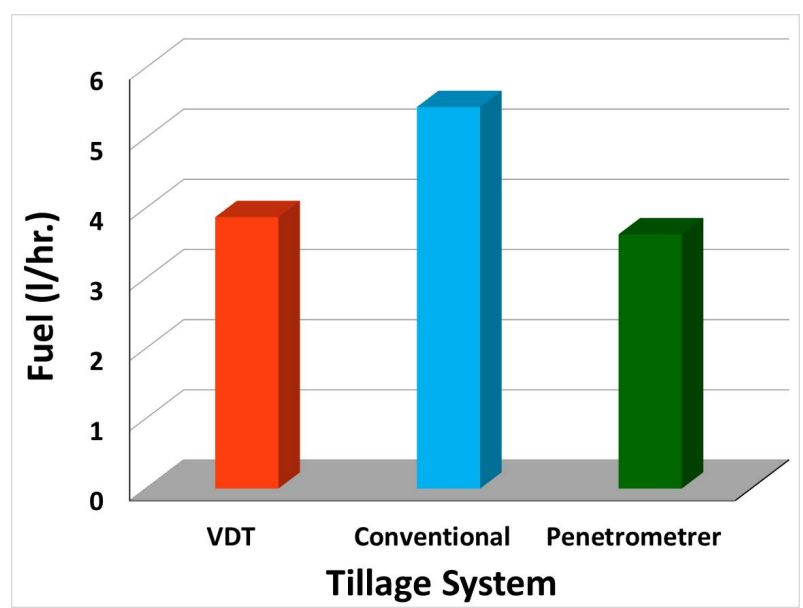

Figure 10. Effects of tillage systems on fuel consumption.

enhances the level of sustainability of the tillage practices by only tilling where needed within a given field. This provides better soil management practices and increases the sustainability of agriculture.

Figure 11 demonstrates the effects of each tillage system on cotton lint yields. Statistically, there were no differences in cotton lint yields between conventional and the variable-depth tillage practices. However, as mentioned earlier, the variable-depth tillage system required significantly $(\mathrm{p}=0.001)$ less fuel during operation. Deep tillage (conventional or variable-rate) increased cotton lint yields by $20 \%$ compared to no-till (NT). Therefore, the Clemson Intelligent Plow has the potential for managing soil compaction in production fields while reducing fuel costs associated with unnecessary deep tillage.

Figure 12 shows the effects of tillage systems on soil compaction at cotton harvest. Cone index values exceeding $2.07 \mathrm{MPa}$, limits root penetration below 


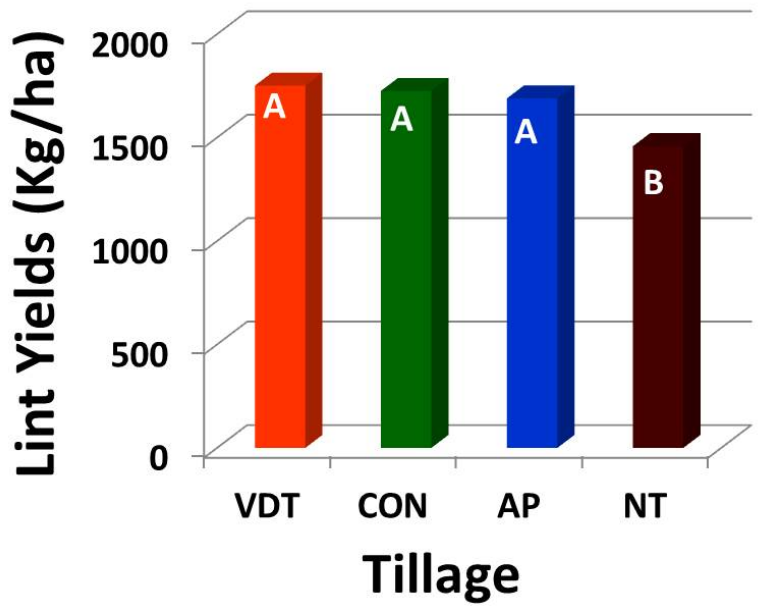

Figure 11. Effects of tillage systems on cotton lint yields (2017). Lint yield values with the same letter are not significantly different at the $95 \%$ confidence level.

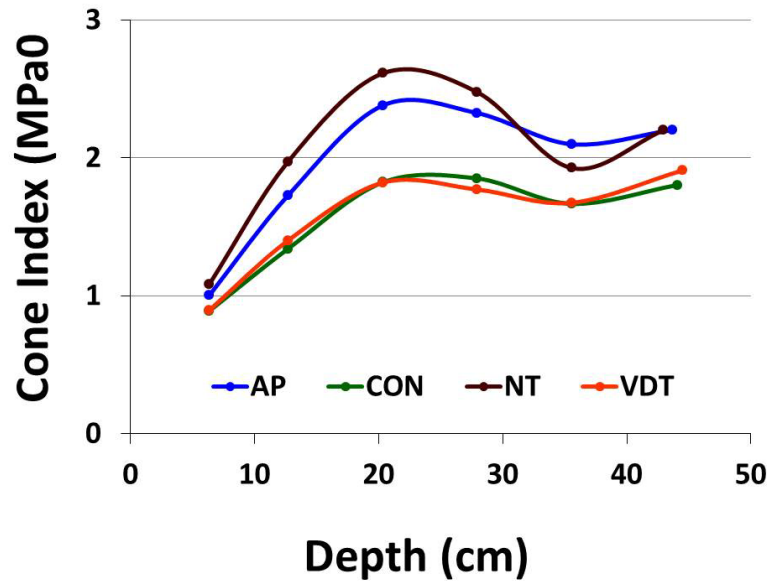

Figure 12. Effects of tillage systems on soil compaction at cotton harvest.

the compaction layer, reducing yields, and making plants more vulnerable to drought stress. Cone index values for both conventional and variable-depth tillage systems were below the limiting value of $2.07 \mathrm{MPa}$ throughout the tillage depth $(38 \mathrm{~cm})$. Both variable-depth and conventional tillage methods significantly reduced soil compaction compared to no-till. Results showed that, tillage operations based on average penetrometer data, did not remove the compacted layer in the test field completely. Cotton taproot length was $14 \%$ less in these plots compared to variable-depth tillage plots. However, the difference was not statistically significant.

This graph also demonstrates that when using controlled traffic for all field operations both conventional and variable depth tillage methods have alleviated the hardpan problem for the entire growing season. Other previous research conducted at Clemson University has shown that deep tillage can alleviate the 
hardpan problem for two or in some cases three years when controlled traffic is practiced [3] [6]. In addition, they reported that there were no differences in lint yield between plots which were deep-tilled in all three years with those which had the tillage operation only in the first year of the test.

\section{Conclusions}

The Clemson Intelligent plow closely followed the design specifications. It measured the mechanical impedance of soil at multiple depths over the upper 45 $\mathrm{cm}$ of the soil profile while moving through the soil. The gage wheels on the plow successfully controlled the tillage depth on-the-go, while maintaining the instrumented shank at a constant depth. With this system, tillage depth could be changed on-the-go from zero to $45 \mathrm{~cm}$. The tillage depth decision-making could be from the instrumented shank (real time) or from soil compaction maps generated using a cone penetrometer measurement system. The tillage depth can also be controlled manually using a one-turn potentiometer located inside the tractor cab.

Replicated field tests were conducted to determine the performance of the Intelligent Plow. Site-specific tillage operations reduced fuel consumption by $45 \%$ compared to conventional constant-depth tillage. Only $20 \%$ of the test field site required tillage at the commonly recommended depth for Coastal Plain regions (38-cm depth). The cotton taproots in the variable-depth tillage plots were $96 \%$ longer than those in the no-till plots. Statistically, there were no differences in cotton lint yield between conventional and the variable-depth tillage. Deep tillage (conventional or variable-rate) increased cotton lint yields by $20 \%$ compared to no-till. Cone index values for both conventional and variable-depth tillage operations (measured at harvest) were below the limiting value of $2.07 \mathrm{MPa}$ throughout the tillage depth $(38 \mathrm{~cm})$. Tillage significantly reduced soil compaction compared to no-till.

\section{Acknowledgements}

Technical Contribution No. 6652 of the Clemson University Experiment Station. This material is based upon work supported by NIFA/USDA, under project number SC-1700540. The authors also acknowledge the funding support of Cotton Incorporated and the Clemson Public Service Activities.

\section{Disclaimer}

Mention of a trade name does not imply endorsement of the product by Clemson University or the USDA to the exclusion of others that might be suitable

\section{References}

[1] Gorucu, S., Khalilian, A., Han, Y.J., Dodd, R.B. and Smith, B.R. (2006) An Algorithm to Determine the Optimum Tillage Depth from Soil Penetrometer Data in Coastal Plain Soils. Applied Engineering in Agriculture, 22, 625-631. https://doi.org/10.13031/2013.21993 
[2] Marshall, M., Williams, P., Mirzakhani-Nafchi, A., Maja, J.M., Payero, J., Mueller, J. and Khalilian, A. (2016) Influence of Tillage and Deep Rooted Winter Cover Crops on Soil Properties, Pests, and Yield Responses in Cotton. Journal of Soil Sciences, 6, 149-158. https://doi.org/10.4236/ojss.2016.610015

[3] Khalilian, A., Jones, M.A., Bauer, P.J. and Marshall, M.W. (2017) Comparison of Five Tillage Systems in Coastal Plain Soils for Cotton Production. Open Journal of Soil Science, 7, 245-258. https://doi.org/10.4236/ojss.2017.710018

[4] Garner, T.H., Khalilian, A. and Sullivan, M.J. (1989) Deep Tillage for Cotton in Coastal Plain Soils-Cost/Returns. Proceedings of the Beltwide Cotton Production Research Conferences, January 1989, Nashville, TN, 168-171.

[5] Khalilian, A., Hood, C.E., Palmer, J.H., Garner, T.H. and Bathke, G.R. (1991) Soil Compaction and Crop Response to Wheat/Soybean Interseeding. Transactions of $A S A E, 34,2299-2303$. https://doi.org/10.13031/2013.31871

[6] Khalilian, A., Jones, M., Sullivan, M., Frederick, J., Bauer, P. and Busscher, W. (2004) Comparison of Strip Tillage Systems in Coastal Plain Soils for Cotton Production. Proceedings of the 2004 Beltwide Cotton Conferences, San Antonio, 5-9 January 2004, 803-810.

[7] Garner, T.H., Reynolds, W.R., Musen, H.L., Miles, G.E., Davis, J.W., Wolf, D. and Peiper, U.M. (1984) Energy Requirement for Subsoiling Coastal Plain Soils. ASAE Paper No. 84-1025. ASAE, St. Joseph.

[8] Reid, J.T. (1978) A Comparison of the Energy Input of Some Tillage Tools. ASAE Paper No. 78-1039. ASAE, St. Joseph.

[9] Campbell, R.B., Reicosky, D.C. and Doty, C.W. (1974) Physical Properties and Tillage of Paleudults in the Southeastern Coastal Plains. Journal of Soil \& Water Conservation, 29, 220-227.

[10] Raper, R.L., Reeves, D.W., Burt, E.C. and Torbert, H.A. (1994) Conservation Tillage and Reduced Traffic Effects on Soil Condition. Transactions of the ASAE, 37, 763-768. https://doi.org/10.13031/2013.28138

[11] Raper, R.L., Schwab, E.B. and Dabney, S.M. (2000) Spatial Variation of the Depth of Root Restricting Layers in Northern Mississippi Soils. Second Int. Conf. Geospatial Information in Agriculture and Forestry, Lake Buena Vista, FL, I-249-I-256.

[12] Garner, T.H., Musen, H.L. and Dodd, R.B. (1986) Management Data for Primary Tillage of Coastal Plain Soils. Proceedings of the 1986 Beltwide Cotton Production Research Conferences, Las Vegas, 4-9 January 1986, 465-466.

[13] Gorucu, S., Khalilian, A., Han, Y.J., Dodd, R.B., Wolak, F.J. and Keskin, M.A. (2001) Variable Depth Tillage Based on Geo Referenced Soil Compaction Data in Coastal Plain Region of South Carolina. ASAE Paper No. 01-1016, ASAE, St. Joseph.

[14] Glancey, J.L., Upadahyaya, S.K., Chancellor, W.J. and Rumsey, J.W. (1989) An Instrumented Chisel for the Study of Soil-Tillage Dynamics. Soil and Tillage Research, 14, 1-24. https://doi.org/10.1016/0167-1987(89)90017-2

[15] Adamchuk, V.I., Morgan, M.T. and Sumali, H. (2001) Application of a Strain Gauge Array to Estimate Soil Mechanical Impedance On-the-Go. Transactions of ASAE, 44, 1377-1383.

[16] Andrade, P., Upadhyaya, S.K., Jenkins, B.M. and Filho, A.G.S. (2002) Evaluation of the UC Davis Compaction Profile Sensor. ASAE Paper No. 02-1185, ASAE, St. Joseph.

[17] Alihamsyah, T., Humphries, E.G. and Bowers, C.G. (1990) A Technique for Horizontal Measurement of Soil Mechanical Impedance. Transactions of the ASAE, 33, 73-77. https://doi.org/10.13031/2013.31296 
[18] Alihamsyah, T. and Humphries, E.G. (1991) On-the-Go Soil Mechanical Impedance Measurements. In: Automated Agric. for the 21 st Century, ASAE, St. Joseph, 300-306.

[19] Chukwu, E. and Bowers, C.G. (1997) Instantaneous Multiple Depth Soil Mechanical Impedance Sensing from a Moving Vehicle. ASAE Paper No. 97-1077, ASAE, St. Joseph.

[20] Hall, H.E. and Raper, R.L. (2005) Development and Concept Evaluation of an On-the-Go Soil Strength Measurement System. Transactions of the ASAE, 48, 469-477. https://doi.org/10.13031/2013.18311

[21] Chung, S.O. (2004) On-the-Go Soil Strength Profile Sensor. PhD Dissertation, University of Missouri, Columbia.

[22] Khalilian, A., Han, Y.J., Marshall, M.W., Gorucu, S., Abbaspour-Gilandeh, Y. and Kirk, K.R. (2014) Evaluation of the Clemson Instrumented Subsoiler Shank in Coastal Plain Soils. Computers and Electronics in Agriculture, 109, 46-51. https://doi.org/10.1016/j.compag.2014.09.002

[23] Khalilian, A., Han, Y.J., Dodd, R.B., Sullivan, M.J., Gorucu, S. and Keskin, M. (2002) A Control System for Variable Depth Tillage. ASAE Paper No. 021209, St. Joseph.

[24] Taylor, H.M. and Gardner, H.R. (1963) Penetration of Cotton Seedlings Taproots as Influenced by Bulk Density, Moisture Content and Strength of Soil. Soil Science, 96, 153-156. https://doi.org/10.1097/00010694-196309000-00001

[25] Gorucu, S., Khalilian, A., Han, Y.J. and Dodd, R.B. (2011) Variable Depth Tillage Based on Geo Referenced Soil Compaction Data in Coastal Plain Soils. International Journal of Applied Science and Technology, 1, 22-32. http://www.ijastnet.com/journals/Vol._1_No._2\%3B_April_2011/4.pdf

[26] Abbaspour, Y., Khalilian, A., Alimardani, R., Keyhani, A. and Sadati, H. (2006) Effects of Soil Texture, Moisture Content, Electrical Conductivity, and Tractor Speed on Energy Requirements of Variable-Depth Tillage. Iranian Journal of Agricultural Science, 35, 473-483. 